\title{
対数正規分布モデルによる地震長期発生確率の計算 —宮城県沖地震の再検討——
}

\author{
気象庁精密地震観測室* 岡 田 正 実
}

\section{Probabilistic Estimation of Large Earthquake Occurrence from Several Earthquakes Using Lognormal Distribution Model}

\section{- Re-evaluation for the Oncoming Earthquake off Miyagi Prefecture, Japan-}

\author{
Masami OKADA \\ Matsushiro Seismological Observatory \\ 3511 Nishijo, Matsushiro-machi, Nagano-shi, 381-1232, Japan
}

(Received December 16, 2002; Accepted January 5, 2004)

\begin{abstract}
I statistically discuss the method for estimating the probability of the next characteristic earthquake in a given time interval from the data on date of earthquakes in the past by using lognormal distribution model, based on the Bayesian approach. We assume that $n+1$ earthquakes have occurred on a fault or in a source area separated by $n$ time intervals, $T_{i}$, of which logarithm, $x_{i}=$ $\ln \left(T_{i}\right)$, are considered to follow a normal distribution, $N\left(\mu, \sigma^{2}\right)$. Here, $\mu$ and $\sigma^{2}$ are mean and variance parameters of a normal population distribution, respectively. Then the likelihood accounted for aseismic period since the last event is defined as $L\left(\mu, \sigma^{2}\right)=\left(1-F_{N}\left(x_{p} ; \mu, \sigma^{2}\right)\right) \prod_{i=1}^{n} f_{N}\left(x_{i} ; \mu, \sigma^{2}\right)$, where $x_{p}, F_{N}$ and $f_{N}$ are the logarithm of the time interval of aseismic period, $T_{p}$, since the last event, the cumulative distribution function, and the probability density function for $N\left(\mu, \sigma^{2}\right)$, respectively. We expect that normalized likelihood represents the density distribution of $\mu, \sigma^{2}$ based on Bayesian rule with a prior distribution of $\pi\left(\mu, \sigma^{2}\right)=1$. If $\mu$ and $\sigma^{2}$ are known, the probability of the next earthquake occurring in the forthcoming period from $T_{p}$ through $T_{p}+\Delta T$ is denoted by a conditional probability, $P_{q}=\left(F_{N}\left(x_{f} ; \mu\right.\right.$, $\left.\left.\sigma^{2}\right)-F_{N}\left(x_{p} ; \mu, \sigma^{2}\right)\right) /\left(1-F_{N}\left(x_{p} ; \mu, \sigma^{2}\right)\right)$, where $x_{f}=\ln \left(T_{p}+\Delta T\right)$. However it is impossible to estimate real values from a small number of data without large error, and we can only know the distribution of parameters to calculate numerically the distribution of $P_{q}$ as shown in this paper. The distribution of expected time interval, $T$, from the last event to the next event is computed analytically from a law that $\sqrt{n-3}(\ln (T)-\bar{x}) / \sqrt{(n+1) s^{2}}$ follows t-distribution of $n-3$ degrees of freedom. Here $\bar{x}$ and $s^{2}$ are mean and variance of data, $x_{i}=\ln \left(T_{i}\right)$. And the expected probability of characteristic earthquake occurrence in a time interval $\Delta T$ given that no earthquake has occurred in $T_{p}$, is the mean of variable $P_{q}$ or a conditional probability of t-distribution. For the characteristic earthquakes off Miyagi prefecture, Japan, the estimates of probability in the periods of 10,20 and 30 years after January 2001 are $0.28,0.62$ and 0.80 , respectively, using the data set compiled by the Earthquake Research Committee of Japan. These estimates for 20 and 30 years are smaller than those, about 0.8 and larger than 0.9 , given by the committee, respectively. Interval estimates of $P_{q}$ for those periods are $0.15-0.41$, $0.42-0.82$ and $0.75-1.0$.
\end{abstract}

Key words: probabilistic prediction, characteristic earthquake, Miyagi-oki earthquake, lognormal distribution, Bayesian approach 
の大地震が近いことを警告したが，その警告通りに東南 海地震 (1944) と南海地震 (1946) が発生した. 1973 年 根室半島沖地震は, 地震空白域の存在と地殼変動デー夕 から発生前にその危険性が指摘されていた [宇津 (1972)].このような長期予湘に関しては, 石橋・佐竹 (1998) や宇津 (1998) によって総合的な報告むされてい る.

地震発生の危険度を表す指標として, 発生確率を採用 し, 活断層や沈み込み帯のプレート境界で繰り返し発生 している大地震について確率予測が試みられた [力武 (1976), Nishenko and Buland (1987)]. その際, 大地震 発生を更新過程と見なし，地震の発生間隔がある特定の 確率分布に従うことが仮定される。米国 Parkfieldにお ける地震でも予測が行われたが, 期間内に地震が発生女 ず，予測方法の問題点や手法の再検討がされた [Bakun and Lindh (1985), Davis et al. (1989), Savage (1993), Working Group on California Earthquake Probabilities (1995)].

Nishenko and Buland (1987)は, 世界各地のプレー 卜境界で発生した固有地震または大地震の発生間隔を調 べ, 対数正規分布がよく適合し, 時間間隔の対数の標準 偏差が世界共通であるとした，そのうえで, 各地域の固 有地震の発生確率を求めた。 これに対し, Davis et al. (1989) は, 対象地域の選定過程で標準偏差の小さいもの が選択されている恐れがあること，地域によっては分散 のパラメータが明らかに異なる固有地震系列があること を指摘した. そのうえで, 尤度に最後の地震からの経過 時間も取り込み, パラメー夕の推定誤差を考慮した平均 尤度法 (mean likelihood method) の概念を用いて地震 発生確率の計算方法を議論し, Parkfield の場合では Nishenko and Buland (1987) が与えた值より確率がか なり小さいことを主張した.

地震間隔の分布としてはいろいろなるのが考えられ る. Utsu (1984) はよく使用されているWeibull 分布, ガンマ分布, 対数正規分布, 2 重指数分布を取り上げ, 南海トラフなどで発生した大地震のデー夕と比較検討し て, 適合度に大差がないことを示した。島崎・他 (1998) は, 内陸の活断層を含めて同様な調査を行い, 適合度に 余り差がないことを確認し, 内陸の顕著な 4 活断層につ いてはばらつきのパラメータが共通と見なせるとした。 地震調查研究推進本部地震調査委員会 (以下「地震調查 委員会」と略す) は, 様々な角度から検討し, 最終的に は地震の発生間隔の分布として, BPT (Brownian Passage Time) 分布を採用した [地震調査研究推進本部地 震調查委員会長期評価部会 $(1998,1999)$, 地震調查研究 推進本部地震調査委員会 (2001)].
その後, 地震調査委員会は, 活断層などの活動度を系 統的に評価し, 大地震の発生確率を相次いで発表してい る. 宮城県沖地震については, 2001 年 1 月から 10 年 間, 20 年間抢よび 30 年間における大地震の発生確率 が，それぞれ約 30\%, 約 80\%抢よび 90\% 以上と非常に 高い[地震調查研究推進本部地震調查委員会 (2000)]. この計算は, 評価手法 [地震調査研究推進本部地震調查 委員会 (2001)] が決まる前であり, 対数正規分布モデル で行われた. Ohtake and Ueda (2002) 屯宮城県沖地震 について同様な調查を行い, 対数正規分布モデルで計算 して，30 年間の発生確率を $97 \%$ としている．その際, 地震調査委員会では地震発生間隔の対数の標本平均々標 本標準偏差が, Ohtake and Ueda では標本平均と標本 不偏分散の平方根が母集団の平均および標準偏差に等し いものとして扱っている. しかし，デー夕数が少ないの で，パラメー夕の推定誤差が確率計算結果に及ぼす影響 が無視できない. 井元 (1999) が指摘しているように, こ のような方法では, 予測確率が 1 に近い之確率の誤差分 布の対称性が崩れ, 得られた結果が期待される確率の平 均値からずれることになる。

ここでは, 従来から行われているように, 繰り返し発 生している固有地震または大地震を更新過程と見なし て, 長期発生確率を計算する方法について考察する。 そ の際, 時間間隔の分布は, 地震調査研究推進本部地震調 查委員会 $(2000)$ と同じく, 対数正規分布であると仮定 する. 計算では, Davis et al. (1989) 々同様に, 尤度関数 に最後の地震からの経過時間も取り込み, 求める発生確 率にパラメータの曖昧さを反映させるようにした. 少数 のデー夕から母集団の平均と分散を精度よく決定するこ とはできないが，事前分布を仮定し，ベイズの定理を使 用すれば，パラメータの分布が推定できる. 求める地震 発生確率は，母集団の平均之分散の関数であり，その確 率分布を厳密に計算する方法を新たに示し，それに基づ いた発生確率の点推定および区間推定の方法を議論す る，その方法を宮城県沖地震に適用し, 結果を地震調査 委員会などの值と比較検討する.

\section{§2. 理論}

過去に $n+1$ 個の地震の発生時期が知られていて, そ れらの時間間隔を $T_{i}$ とする. 最後の地震から予測時点 までの経過時間を $T_{p}$ とし, 予測期間を $\Delta T$ とする. $T$, $T_{p}$ および $T_{p}+\Delta T$ の自然対数を $x_{i}, x_{p}$ および $x_{f}$ とする. 対数正規分布モデルでは， $x_{i}$ は正規分布に従うと仮定さ れる。

\section{1 尤度関数と母集団パラメータの分布}

正規分布 $N\left(\mu, \sigma^{2}\right)$ の確率密度関数 $f_{N}\left(x ; \mu, \sigma^{2}\right)$ は, 


$$
f_{N}\left(x ; \mu, \sigma^{2}\right)=\frac{1}{\sqrt{2 \pi \sigma}} \exp \left\{-\frac{(x-\mu)^{2}}{2 \sigma^{2}}\right\}
$$

である. 累積分布関数 $F_{N}\left(x ; \mu, \sigma^{2}\right)$ を

$$
F_{N}\left(x ; \mu, \sigma^{2}\right)=\int_{-\infty}^{x} f_{N}\left(x ; \mu, \sigma^{2}\right) d x
$$

とする. パラメータ $\mu, \sigma^{2}$ の事前分布 $\pi\left(\mu, \sigma^{2}\right)$ は, 事前に 有効な情報がないので,

$$
\pi\left(\mu, \sigma^{2}\right)=1
$$

と仮定する.

尤度関数 $L\left(\mu, \sigma^{2}\right)$ は, 最後の地震から予測日までの間 に地震が発生していないことを考慮すると，

$$
L\left(\mu, \sigma^{2}\right)=\left\{1-F_{N}\left(x_{p} ; \mu, \sigma^{2}\right)\right\} \prod_{i=1}^{n} f_{N}\left(x_{i} ; \mu, \sigma^{2}\right)
$$

と定義される[例えば Ogata (1978), Davis et al. (1989)]. 標本平均 $\bar{x}$ 之標本分散 $s^{2}$

$$
\begin{aligned}
& \bar{x}=\frac{1}{n} \sum_{i=1}^{n} x_{i} \\
& s^{2}=\frac{1}{n} \sum_{i=1}^{n}\left(x_{i}-\bar{x}\right)^{2}
\end{aligned}
$$

を使うと

$$
\begin{aligned}
L\left(\mu, \sigma^{2}\right)= & \left\{1-F_{N}\left(x_{p} ; \mu, \sigma^{2}\right)\right\}\left(\frac{1}{2 \pi \sigma^{2}}\right)^{n / 2} \\
& \times \exp \left\{-\frac{n s^{2}+n(\bar{x}-\mu)^{2}}{2 \sigma^{2}}\right\}
\end{aligned}
$$

または

$$
\begin{aligned}
& L\left(\mu, \sigma^{2}\right)=\left(\frac{1}{2 \pi \sigma^{2}}\right)^{(n+1) / 2} \\
& \quad \times \int_{x_{p}}^{\infty} \exp \left\{-\frac{(u-\mu)^{2}+n s^{2}+n(\bar{x}-\mu)^{2}}{2 \sigma^{2}}\right\} d u
\end{aligned}
$$

となり, $L\left(\mu, \sigma^{2}\right)$ は $n, \bar{x}, s^{2}$ および $x_{p}$ の関数となる.

ベイズの定理から, 期待される $\mu, \sigma^{2}$ の同時密度分布 は

$$
h\left(\mu, \sigma^{2} \mid n, \bar{x}, s^{2}, x_{p}\right) d \mu d \sigma^{2}=\frac{L\left(\mu, \sigma^{2}\right)}{C} d \mu d \sigma^{2}
$$

で与えられる.ここで $C$ は

$$
\begin{aligned}
C= & \int_{\sigma^{2}=0}^{\infty} \int_{\mu=-\infty}^{\infty} L\left(\mu, \sigma^{2}\right) d \mu d \sigma^{2} \\
= & \int_{\sigma^{2}=0}^{\infty} \int_{\mu=-\infty}^{\infty} \int_{\mu=x_{p}}^{\infty} f_{N}\left(u ; \mu, \sigma^{2}\right) \\
& \times \prod_{i=1}^{n} f_{N}\left(x_{i} ; \mu, \sigma^{2}\right) d u d \mu d \sigma^{2} \\
= & \int_{\sigma^{2}=0}^{\infty} \int_{\mu=-\infty}^{\infty} \int_{\mu=x_{p}}^{\infty}\left(\frac{1}{\sqrt{2 \pi \sigma^{2}}}\right)^{n+1} \\
& \times \exp \left\{-\frac{(u-\mu)^{2}+n s^{2}+n(\bar{x}-\mu)^{2}}{2 \sigma^{2}}\right\} d u d \mu d \sigma^{2}(10)
\end{aligned}
$$

である. 右辺の被積分関数は,

$$
\begin{aligned}
& \left(\frac{1}{\sqrt{2 \pi \sigma^{2}}}\right)^{n+1} \exp \left\{-\frac{(u-\mu)^{2}+n s^{2}+n(\bar{x}-\mu)^{2}}{2 \sigma^{2}}\right\} \\
& =\frac{1}{\sqrt{n+1}(\sqrt{2 \pi})^{n}} J^{(n-2) / 2} \Gamma\left(\frac{n-2}{2}\right) \\
& \quad \times \frac{\sqrt{n+1}}{\sqrt{2 \pi \sigma^{2}}} \exp \left\{-\frac{(n+1)}{2 \sigma^{2}}\left(\mu-\frac{u+n \bar{x}}{n+1}\right)^{2}\right\} \\
& \quad \times \frac{J}{\Gamma\left(\frac{n-2}{2}\right)}\left(-\frac{1}{\sigma^{2} J}\right)^{((n-2) / 2)+1} \\
& \quad \times \exp \left(-\frac{1}{\sigma^{2} J}\right)
\end{aligned}
$$

と書き換えることができる.ここで

$$
J=\frac{2(n+1)}{n\left\{(\bar{x}-u)^{2}+(n+1) s^{2}\right\}}
$$

である. (10) 式では, 積分区間が他の積分変数に依存し ないので, 積分の順序を入れ替えることができる．最初 に $\mu$ について積分すると, (11) 式右辺の第 2 項が 1 と

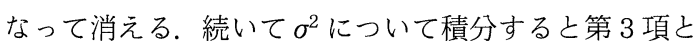
第 4 項が 1 となるので,

$$
C=\frac{\Gamma\left(\frac{n-2}{2}\right)}{\sqrt{n+1}(\sqrt{2 \pi})^{n}}\left\{\frac{2(n+1)}{n}\right\}^{(n-2) / 2}
$$

$$
\times \int_{x_{p}}^{\infty} \frac{1}{\left\{(u-\bar{x})^{2}+(n+1) s^{2}\right\}^{(n-2) / 2}} d u
$$

である. $u$ に関する積分式の不定積分を $G\left(u ; n, \bar{x}, s^{2}\right)$ と すれば,

$$
\begin{aligned}
C= & \frac{\Gamma\left(\frac{n-2}{2}\right)}{\sqrt{n+1}(\sqrt{2 \pi})^{n}}\left\{\frac{2(n+2)}{n}\right\}^{(n-1) / 2} \\
& \times\left\{G\left(\infty ; n, \bar{x}, s^{2}\right)-G\left(x_{p} ; n, \bar{x}, s^{2}\right)\right\}
\end{aligned}
$$

となる. $G\left(u ; n, \bar{x}, s^{2}\right)$ の数式表現は, $n$ が奇数ならば, $m$ $=(n-3) / 2$ と置くと,

$$
\begin{aligned}
& G\left(u ; n, \bar{x}, s^{2}\right)=\int\left\{\frac{1}{(u-\bar{x})^{2}+(n+1) s^{2}}\right\}^{(2 m-1) / 2} d u \\
& =\frac{1}{\left\{(n+1) s^{2}\right\}^{m}} \sum_{r=0}^{m+1} \frac{(-1)^{r}}{2 r+1}\left(\frac{m-1}{r}\right) \\
& \quad \times\left\{\frac{u-\bar{x}}{\sqrt{(u-\bar{x})^{2}+(n+1) s^{2}}}\right\}^{2 r+1}
\end{aligned}
$$

であり, $n$ が偶数のときは, $m=(n-2) / 2$ と置くと, $G\left(u ; n, \bar{x}, s^{2}\right)$

$$
=\int\left\{\frac{1}{(u-\bar{x})^{2}+(n+1) s^{2}}\right\}^{m} d u=\frac{(2 m-3) ! !}{(m-1) !}
$$




$$
\times\left[\begin{array}{l}
\sum_{r=1}^{m-1} \frac{(m-r-1) !}{(2 m-2 r-1) ! !} \frac{1}{\left\{2(n+1) s^{2}\right\}^{r}} \\
\times \frac{u-\bar{x}}{\left\{(u-\bar{x})^{2}+(n+1) s^{2}\right\}^{m-r}} \\
+\frac{1}{\left\{2(n+1) s^{2}\right\}^{m-1}} \frac{1}{\sqrt{(n+1) s^{2}}} \\
\times \arctan \left\{\frac{u-\bar{x}}{\sqrt{(n+1) s^{2}}}\right\}
\end{array}\right]
$$

となる [例えば，森口・他 (1956)]，!!印がついた $(2 m-$ $3) ! !$゙よ゙は $(2 m-3) ! !=(2 m-3)(2 m-5) \cdots 3 \cdot 1$ などを表 す.

\section{2 地震発生確率の確率分布}

予測期間 $\left(T_{p} \sim T_{p}+\Delta T\right)$ 内に地震が発生する確率 $P_{q}$ $\left(T_{p}, T_{p}+\Delta T\right)$ は, $T_{p}$ まで地震が発生しておらず，それ以 後に発生するので, 条件付き確率

$$
P_{q}\left(T_{p}, T_{p}+\Delta T\right)=\frac{F_{N}\left(x_{f} ; \mu, \sigma^{2}\right)-F_{N}\left(x_{p} ; \mu, \sigma^{2}\right)}{1-F_{N}\left(x_{p} ; \mu, \sigma^{2}\right)}
$$

となる.この式の值は， $\mu, \sigma^{2}$ が既知であれば容易に計算 できるが，実際の場合は $\mu, \sigma^{2}$ の正確な值が分からない． しかし, ベイズの定理から $\mu, \sigma^{2}$ の分布が (9) 式で表され るので, $P_{q}\left(T_{p}, T_{p}+\Delta T\right)$ の確率分布は以下のようにして 計算できる

$P_{q}\left(T_{p}, T_{p}+\Delta T\right)$ の累積分布関数を $F_{P}\left(p ; n, \bar{x}, s^{2}, T_{p}\right.$, $\Delta T)$ とすれば, その定義から

$$
\begin{aligned}
F_{P}\left(p ; n, \bar{x}, s^{2}, T_{p}, \Delta T\right) & =\operatorname{Pr}\left\{P_{q}\left(T_{p}, T_{p}+\Delta T\right) \leq p\right\} \\
& =\iint_{S} h\left(\mu, \sigma^{2}\right) d \mu d \sigma^{2}
\end{aligned}
$$

となる.ここで, Pr は確率を意味し, $p$ の変域は $0 \leq p \leq$ 1 で, 積分領域 $S$ は,

$$
S=\left\{\left(\mu, \sigma^{2}\right) \mid \frac{F_{N}\left(x_{f} ; \mu, \sigma^{2}\right)-F_{N}\left(x_{p} ; \mu, \sigma^{2}\right)}{1-F_{N}\left(x_{p} ; \mu, \sigma^{2}\right)} \leq p\right\}
$$

である．積分領域を解析的に求めることは容易でないの で, $P_{q}\left(T_{p}, T_{p}+\Delta T\right)$ の分布は, 観測データが与えられて から (18) 式で数值的に計算する.

一例として, 宮城県沖地震の 30 年間発生確率 $P_{q}\left(T_{p}\right.$, $\left.T_{p}+30\right)$ の場合を紹介する．計算条件 $(n=5, \bar{x}=3.598$, $\left.s^{2}=0.031, x_{p}=3.1157, x_{f}=3.962, \Delta T=30\right)$ は地震調查 研究推進本部地震調査委員会 $(2000)$ が採用したデー夕 から求めたあのである. $\mu, \sigma$ に対する $P_{q}\left(T_{p}, T_{p}+\Delta T\right)$ お よび $h(\mu, \sigma)$ の分布は Fig. 1 と Fig. 2 のようになる.こ れらの図では，表示の都合で， $\mu, \sigma^{2}$ の代わりに $\mu-\bar{x}, \sigma$ を独立変数として採用して抢り， $h$ あ $\mu-\bar{x}, \sigma$ に対する 確率密度

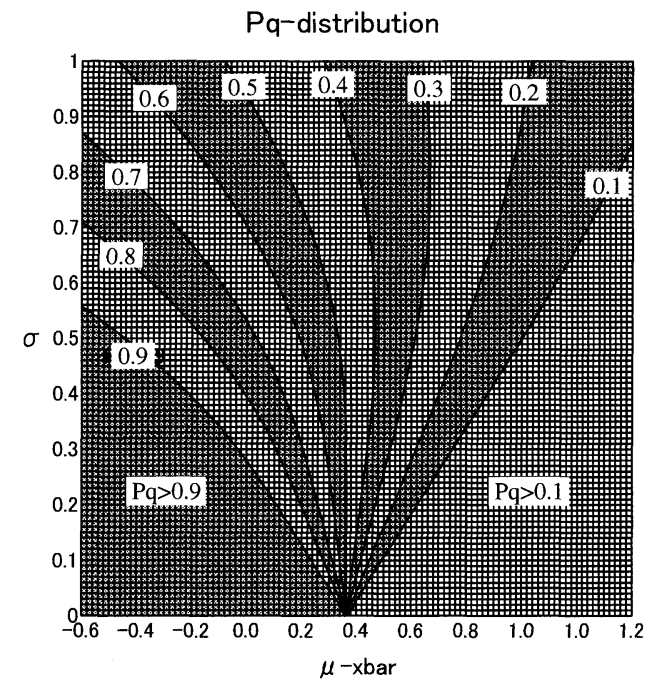

Fig. 1. Conditional probability, $P_{q}$, for the occurrence of characteristic earthquake off Miyagi prefecture in 30 years since January 2001 as a function of population parameters, $\mu$ and $\sigma$. " $x$ bar" is the mean of $x_{i}=\ln \left(T_{i}\right)$, which are obtained from the data set I compiled by the Earthquake Research Committee of Japan.

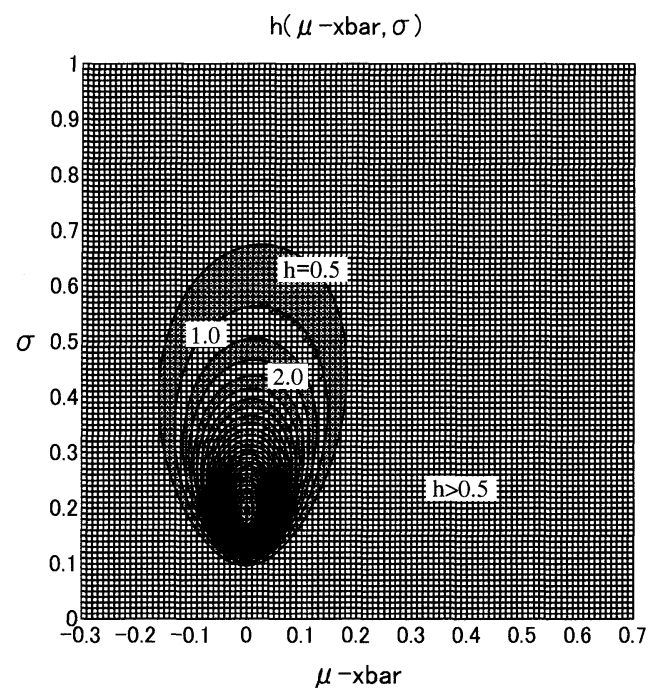

Fig. 2. Normalized likelihood function at January 2001 for the data set I which is compiled by the Earthquake Research Committee of Japan. The interval of contours corresponds 0.5 and the peak is 14.2 in normalized likelihood. 


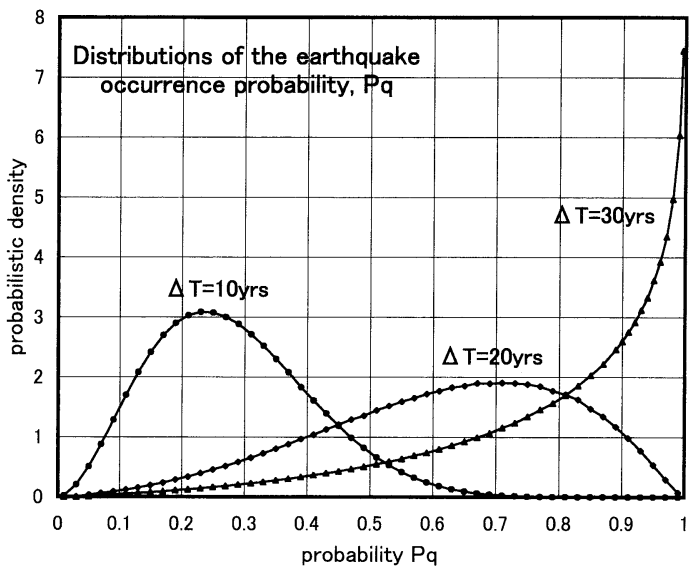

Fig. 3. Distribution of the probabilities, $P_{q}$, for the occurrence of characteristic earthquake off Miyagi prefecture since January 2001 estimated from the data set I.

$$
\begin{aligned}
h^{\prime}(\mu-\bar{x}, \sigma)= & \frac{2 \sigma}{C}\left\{1-F_{N}\left(x_{p} ; \mu, \sigma^{2}\right)\right\}\left(\frac{1}{2 \pi \sigma^{2}}\right)^{n / 2} \\
& \times \exp \left\{-\frac{n s^{2}+n(\bar{x}-\mu)^{2}}{2 \sigma^{2}}\right\}
\end{aligned}
$$

を表している. Fig. 1 で $\sigma$ が小さくなると，等值線が $\mu$ $-\bar{x}=x_{f}-\bar{x}=0.364$ に集中しているが，これは $x_{f}$ が $\mu$ よ り大きいか小さいかによって確率 $P_{q}\left(T_{p}, T_{p}+\Delta T\right)$ が大 きく変化するためである. Fig. 2 に示した $h^{\prime}(\mu-\bar{x}, \sigma)$ の 分布は, 直線 $\mu-\bar{x}=0$ に対してわずかに非対称になる.

(19) 式の $p$ が与えられると, Fig. 1 に示すような $P_{q}$ $\left(T_{p}, T_{p}+\Delta T \mid \mu, \sigma\right)=p$ となる等值線が決まり, 積分領域 $\mathrm{S}$ はその曲線の右側 ( $\mu$ の大きい部分) となる. 分布関数 $F_{P}\left(p ; n, \bar{x}, s^{2}, T_{p}, \Delta T\right)$ の值は, 領域 $\mathrm{S}$ で $h^{\prime}(\mu, \sigma)$ を積分 したものである. 結果として Fig. 3 に示すような $P_{q}\left(T_{p}\right.$, $\left.T_{\mathrm{p}}+\Delta T\right)$ の確率分布が得られる. 宮城県沖地震の場合は 予測期間 $\Delta T=10$ 年および 20 年だと非対称な凸型分布 となるが, $\Delta T=30$ 年の場合は $\mathrm{J}$ 字型分布となる.

\section{3 地震発生確率の期待値}

地震発生の危険性を表現するために, 地震発生確率を 使用するのであれば, $P_{q}\left(T_{p}, T_{p}+\Delta T\right)$ の分布の代表值で ある期待値 (平均) や中央值を採用することが考えられ る. 最頻值 (モード) は, Fig. 3 の $\Delta T=30$ 年の場合の ように, J字型分布の場合があるので, 適当でない. 筆者 は, $\Gamma n, \bar{x}, s^{2}, T_{p}, \Delta T$ が同じ活断層等が多数あった場合 に, 予測期間内に地震が発生する割合は $P_{q}\left(T_{p}, T_{p}+\Delta T\right)$ の期待値 (平均) $\bar{P}\left(T_{p}, T_{p}+\Delta T\right)$ であり, その值が地震発 生の危険性を表す点推定として最む適している.」と考 える. そこで, Davis et al. (1989) と同様に, 地震発生確 率の点推定として, $P_{q}\left(T_{p}, T_{p}+\Delta T\right)$ の期待值 (平均) $\bar{P}_{q}$
$\left(T_{p}, T_{p}+\Delta T\right)$ を採用する.

$\bar{P}_{q}\left(T_{p}, T_{p}+\Delta T\right)$ は解析的に計算できることも好都合 である. 具体的には,

$$
\begin{aligned}
\bar{P}_{q}= & \bar{P}_{q}\left(T_{p}, T_{p}+\Delta T\right)=E\left\{\frac{F_{N}\left(x_{f} ; \mu, \sigma^{2}\right)-F_{N}\left(x_{p} ; \mu, \sigma^{2}\right)}{1-F_{N}\left(x_{p} ; \mu, \sigma^{2}\right)}\right\} \\
= & \int_{\sigma^{2}=0}^{\infty} \int_{\mu=-\infty}^{\infty} \frac{F_{N}\left(x_{f} ; \mu, \sigma^{2}\right)-F_{N}\left(x_{p} ; \mu, \sigma^{2}\right)}{1-F_{N}\left(x_{p} ; \mu, \sigma^{2}\right)} \\
& \times h\left(\mu, \sigma^{2} \mid x_{1}, x_{2}, \cdots, x_{n} ; x_{p}\right) d \mu d \sigma^{2}
\end{aligned}
$$

である. (2), (4), (9) 式を(21) 式に代入すると，(4) 式に現 れる $1-F_{N}\left(x_{p} ; \mu, \sigma^{2}\right)$ と $(21)$ 式分母の $1-F_{N}\left(x_{p} ; \mu, \sigma^{2}\right)$ と が打ち消す。積分の順序を入れ替えると,

$$
\bar{P}_{q}=\frac{\left[\begin{array}{c}
\int_{u=x_{p}}^{x_{f}} \int_{\sigma^{2}=0}^{\infty} \int_{\mu=-\infty}^{\infty} f_{N}\left(u ; \mu, \sigma^{2}\right) \\
\times \prod_{i=1}^{n} f_{N}\left(x_{i} ; \mu, \sigma^{2}\right) d \mu d \sigma^{2} d u
\end{array}\right]}{\left[\begin{array}{l}
\left.\int_{u=x_{p}}^{\infty} \int_{\sigma^{2}=0}^{\infty} \int_{\mu=-\infty}^{\infty} f_{N}\left(u ; \mu, \sigma^{2}\right)\right] \\
\times \prod_{i=1}^{n} f_{N}\left(x_{i} ; \mu, \sigma^{2}\right) d \mu d \sigma^{2} d u
\end{array}\right]}
$$

となる. 被積分関数は (10) 式と同じであり, 解析的に積 分でき,

$$
\bar{P}_{q}=\frac{G\left(x_{f} ; n, \bar{x}, s^{2}\right)-G\left(x_{p} ; n, \bar{x}, s^{2}\right)}{G\left(\infty ; n, \bar{x}, s^{2}\right)-G\left(x_{p} ; n, \bar{x}, s^{2}\right)}
$$

となる. 関数 $G\left(x ; n, \bar{x}, s^{2}\right)$ は (15) または (16) 式で定義さ れる.

\section{4 地震発生間隔の分布}

最後の地震から次の地震までの時間間隔 $T$ の分布が どのようになるかを検討する. 最後の地震が発生した直 後 $T \rightarrow 0$ を想定すると, $x_{p}=-\infty$ ありり, 時間間隔の対 数 $x$ の累積分布関数 $F\left(x ; n, \bar{x}, s^{2}\right)$ は, (23) 式加ら

$$
F\left(x ; n, \bar{x}, s^{2}\right)=\frac{G\left(x ; n, \bar{x}, s^{2}\right)-G\left(-\infty ; n, \bar{x}, s^{2}\right)}{G\left(\infty ; n, \bar{x}, s^{2}\right)-G\left(-\infty ; n, \bar{x}, s^{2}\right)}
$$

となる。これに対応する確率密度関数 $f\left(x ; n, \bar{x}, s^{2}\right)$ は, (24) 式を微分して, $f\left(x ; n, \bar{x}, s^{2}\right)=$

$$
\frac{\Gamma\left(\frac{n-2}{2}\right)\left\{(n+1) s^{2}\right\}^{(n-3) / 2}}{\sqrt{\pi} \Gamma\left(\frac{n-3}{2}\right)\left\{(x-\bar{x})^{2}+(n+1) s^{2}\right\}^{(n-2) / 2}}
$$

となる. (23) 式は, 最後の地震から予測時点まで地震が 発生していないという条件下の確率（条件付き確率）で あるのに対し，(24), (25) 式はそのような条件のないxの 確率 (無条件確率) である. 条件付き確率 $\bar{P}_{q}\left(T_{p}, T_{p}+\right.$ $\Delta T)$ は無条件確率 $F\left(x ; n, \bar{x}, s^{2}\right)$ を用いれば,

$$
\bar{P}_{q}=\frac{F\left(x_{f} ; n, \bar{x}, s^{2}\right)-F\left(x_{p} ; n, \bar{x}, s^{2}\right)}{1-F\left(x_{p} ; n, \bar{x}, s^{2}\right)}
$$




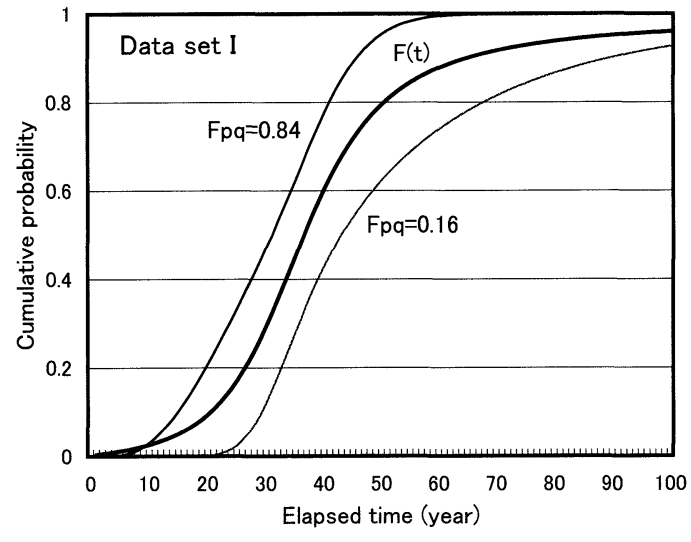

Fig. 4. Expected cumulative distribution, $F(t)$, of the time interval between the last earthquake and the next one and the interval estimates. $F_{p q}=0.16$ and $F_{p q}=0.84$ correspond the points at which cumulative distribution function of $P_{q}$ is equal to 0.16 and 0.84 , respectively.

と簡明に表現され，解析的に計算できる.

さらに, (25) 式で,

$$
t=\frac{\sqrt{n-3}(x-\bar{x})}{\sqrt{(n+1) s^{2}}}
$$

とおけば, $\sqrt{n-3} d x=\sqrt{(n+1) s^{2}} d t$ であり, $t$ の密度関 数 $f_{t}\left(t ; n, x, s^{2}\right)$ は

$f_{t}\left(t ; n, \bar{x}, s^{2}\right)=$

$$
\frac{\Gamma\left(\frac{n-2}{2}\right)}{\sqrt{(n-3) \pi} \Gamma\left(\frac{n-3}{2}\right)} \frac{1}{\left(1+\frac{t^{2}}{n-3}\right)^{(n-2) / 2}}
$$

となる.したがって, (27) 式の $t$ 值は自由度 $n-3$ の t分布に従うことが分かる.

時間間隔の累積分布（無条件確率分布）の例を Fig. 4 に示す. (24) 式または (25) 式で変数変換 $T=\exp (x)$ を すれば $T$ の分布が得られる. $n, \bar{x}, s^{2}$ は, 宮城県沖地震の 值 [地震調查研究推進本部地震調査委員会 $(2000)$ ] 使 用した. 図の横軸は, $x=\ln (T)$ ではなく, 最後の地震か らの経過時間 $T$ (年) を採用してある. $T$ が小さくなる 之, 比較的速く確率が 0 に近づくのに対し, 経過時間が 平均発生間隔を超えて大きくなった場合は, 確率が 1 に 近づくのが遅いことが分かる. また，区間推定（推定誤 差) の目安として, $P_{q}$ の累積分布 $[(18)$ 式 $]$ で確率 $\operatorname{Pr}=$ 0.16 と 0.84 に対応する $p$ の曲線む示してある. これら の曲線の間の確率はいつの時点でも 0.68 で, 正規分布 の平均土標準偏差に対応している. 経過時間 $T$ が 10 年 末満だと, 平均が $\mathrm{Pr}=0.84$ の曲線より上に位置してい

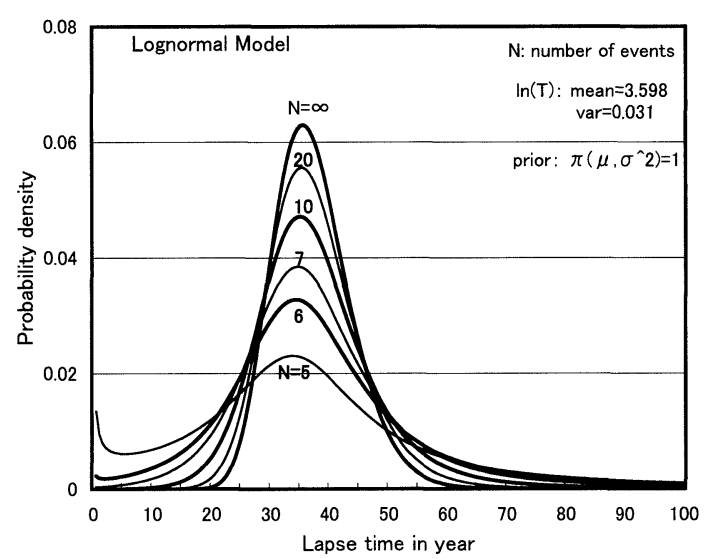

Fig. 5. Dependence of the distributions for a time interval from the last earthquake to the next one on the number of events.

る.これは, $P_{q}$ の分布の非対称性が著しく, $\operatorname{Pr}=0.84$ の 点より平均值が大きくなることを意味している.

地震の個数 $N(=n+1)$ によって, 予想される時間間隔 $T$ の分布（無条件確率分布）がどのように変わるかを示 したのが Fig. 5 である. $\bar{x}, s^{2}$ は, Fig. 4 の場合と同じ く, 宮城県沖地震の值を使用した。地震が 5,6 個と少な い場合は, 対数正規分布 $(n=\infty$ の場合）と大きく異な り，モード値の確率密度が半分程度にしかならない．地 震数が少ないと偶然的な要因によって，与えられた標本 值 $\left(\bar{x}, s^{2}\right)$ をとりうる可能性が高いので, 分散が大きくな る. ピークの位置がずれるのは, 横軸に $x=\ln (T)$ ではな く, 経過時間 $T$ を採用したためである.なお, 今回採用 した事前分布では，(28) 式などから分かるように，地震 数 $N$ が 4 個以下になると地震発生確率を計算すること ができない.

\section{§3. 宮城県沖地震への適用}

\section{1 データセット}

宮城県沖では, 数十年間隔で $M 7.5$ 前後の地震が繰り 返し発生し，その活動が注目されてきた[瀬野 (1979), Utsu (1984)]. 瀬野 (1979) は, それらの発生域を宮城近 海とその沖合域に分けてまとめており, Table 1 は宮城 近海で発生したとされている地震のリストである.

1793 年の地震は海溝よりの区域で発生したが, 破壊域 が沿岸域まで及んだ公算があるとされている. Utsu (1984) によると, 1646 年, 1736 年および 1770 年の地 震は内陸域で発生した可能性がある。 また, 地震調查研 究推進本部地震調査委員会 (2000) では, 1793 年より前 の地震については, データが十分でないと判断し, 評価 を行っていない. Ohtake and Ueda (2002) では, 資料 
Table 1. Large earthquakes off Miyagi prefecture.

\begin{tabular}{|c|c|c|c|c|c|c|}
\hline \multirow{2}{*}{ date } & \multirow{2}{*}{$M$} & \multirow{2}{*}{$\begin{array}{c}T_{i} \\
\text { year }\end{array}$} & \multicolumn{4}{|c|}{ data set } \\
\hline & & & I & II & III & IV \\
\hline 9 Sept. 1616 & 7.0 & & & & 0 & 0 \\
\hline 9 June 1646 & 7.6 & 29.7 & & & 0 & 0 \\
\hline 2 Oct. 1678 & 7.4 & 32.3 & & & 0 & 0 \\
\hline 30 Apr. 1736 & 6.2 & 57.6 & & & $\bigcirc$ & 0 \\
\hline 27 May 1770 & 7.4 & 34.1 & & & 0 & \\
\hline 17 Feb. 1793 & 7.7 & 22.7 & 0 & & $\bigcirc$ & 0 \\
\hline 20 July 1835 & 7.5 & 42.4 & $\bigcirc$ & $\bigcirc$ & $\bigcirc$ & 0 \\
\hline 21 Oct. 1861 & 7.4 & 26.3 & 0 & $\bigcirc$ & $\bigcirc$ & 0 \\
\hline 20 Feb. 1897 & 7.4 & 35.3 & 0 & 0 & 0 & 0 \\
\hline 3 Nov. 1936 & 7.5 & 39.7 & $\bigcirc$ & $\bigcirc$ & 0 & 0 \\
\hline 12 June 1978 & 7.4 & 41.6 & 0 & $\bigcirc$ & $\bigcirc$ & 0 \\
\hline
\end{tabular}

note: $T_{i}$ is the time interval between successive events.

Table 2. Conditional probability of large earthquake occurrence off Miyagi prefecture after 1 January 2001.

\begin{tabular}{|c|c|c|c|c|c|c|}
\hline \multirow{2}{*}{ data set } & \multirow{2}{*}{$n$} & \multirow{2}{*}{ mean of $\ln \left(T_{i}\right)$} & \multirow{2}{*}{ variance of $\ln \left(T_{i}\right)$} & \multicolumn{3}{|c|}{$\Delta T$, year } \\
\hline & & & & 10 & 20 & 30 \\
\hline I & 5 & 3.598 & 0.0310 & $\begin{array}{c}0.279 \\
(0.3)\end{array}$ & $\begin{array}{c}0.618 \\
(0.8)\end{array}$ & $\begin{array}{c}0.796 \\
(\geqq 0.9)\end{array}$ \\
\hline II & 4 & 3.561 & 0.0318 & 0.268 & 0.533 & 0.675 \\
\hline III & 10 & 3.556 & 0.0634 & 0.344 & 0.689 & 0.866 \\
\hline IV & 9 & 3.661 & 0.0644 & 0.248 & 0.572 & 0.787 \\
\hline
\end{tabular}

note: Numbers in parentheses are probabilities by the Earthquake Research Committee of Japan.

を最近 200 年間に限定し，最近の 5 個のみを使用して いる. Table 1 のマグニチュードは, 最近の 3 例が Utsu (1984) に，それ以外は瀬野 (1979) に掲載されている值 である．直前の地震からの経過年数は，地震調査研究推 進本部地震調查委員会長期評価部会 (1999) からの転載 である.

長期発生確率を計算するためのデータセットとして は, 地震調査研究推進本部地震調查委員会 $(2000)$ 打よ び Ohtake and Ueda (2002) が使用したもの取り上げ, それぞれデータセットI，データセットII とする．地震 数を増やした場合として, 地震調查研究推進本部地震調 查委員会長期評価部会 (1999) と同様に, Table 1 の地震 全部からなるデータセット III と, 1770 年の地震を除い たデータセット IV を取り上げた. 1770 年の地震は震央 が全くあいまいであるとされている [Utsu (1984)].これ らのデータセットを用いて, 地震発生確率の推定を行 う.

\section{2 点推定}

データセットIから発生間隔の自然対数 $\left(=\ln \left(T_{i}\right)\right)$ の 標本平均 $\bar{x}$ 之標本分散 $s^{2}$ を求めると, $\bar{x}=3.598, s^{2}=$
0.031 である. また, 最新の地震から予測時点 (2001 年 1 月 1 日）までの経過年数は 22.55 年である. 地震数は $N=6$ で, 発生間隔のデー夕数は $n=5$ である. $m=(n-$ $3) / 2=1$ となるので, (15) 式は,

$$
G\left(u ; n, \bar{x}, s^{2}\right)=\frac{1}{6 s^{2}} \frac{u-\bar{x}}{\sqrt{(u-\bar{x})^{2}+6 s^{2}}}
$$

となる，予測時点（2001 年 1 月 1 日）までの経過時間 (22.55 年) の対数 $x_{p}=3.1157$ で, 予測時点から 10 年 後, 20 年後, 30 年後までの経過時間の対数 $x_{f}$ は 3.483 , $3.751,3.962$ である. したがって, 10 年後, 20 年後, 30 年後までの地震発生確率 $\bar{P}$ は, (23), (29) 式からそれぞ れ $0.28,0.62,0.80$ となる. Table 2 の括弧内の値は地震 調査研究推進本部地震調査委員会 (2000) が発表してい るむのであるが，それに比べると，今回の結果は 20 年 間执よび 30 年間の值がかなり小さい.

その他のデータセットについて発生確率を計算した結 果む Table 2 に掲載してある. Ohtake and Ueda (2002) が宮城県沖地震として採用したデータセット II では, 30 年間の発生確率の期待值が 0.68 となり, 彼ら が求めた值 0.97 より大幅に低下する。データセットI 
より平均発生間隔は短いが, 地震数が少ないために, 発 生確率は小さくなる，データセットIII の場合は，地震 数が多くかつ平均発生間隔が短いので, 確率が最も高 い. データセット IV は, 平均発生間隔が最も長く, 分散 が大きいが, 30 年間の発生確率ではデータセット I と ほぼ同じである。

\section{3 区間推定}

データセットIについて, 地震発生確率 $P_{q}$ の確率分 布を Fig. 3 に示してあるが，予測期間 $\Delta T=10$ 年， 20 年, 30 年について, 確率の期待值 $\bar{P}$, 分散 $v$ および標準 偏差 $s_{q}$ は

$$
\begin{array}{r}
\Delta T=10 \text { 年: } \bar{P}=0.28, v=0.0159, s_{q}=0.126 \\
20 \text { 年: } \bar{P}=0.62, v=0.0380, s_{q}=0.195 \\
30 \text { 年: } \bar{P}=0.80, v=0.0375, s_{q}=0.194
\end{array}
$$

である.ここで用いた $\bar{P}$ 值は, 数値計算で求めた $P_{q}\left(T_{p}\right.$, $\left.T_{p}+\Delta T\right)$ の分布から計算したものであるが，解析解 [(23) 式と (29) 式] で求めたものにほぼ完全に一致して おり, 分布計算では必要な精度が保たれていることを示 唆している.

区間推定を “平均土標準偏差” で表すと, $\Delta T=10$ 年, 20 年, 30 年の場合それぞれの值は $P_{q}=0.28 \pm 0.126$, $0.62 \pm 0.195,0.80 \pm 0.194$ となり，これらの推定区間内 の確率は $0.67,0.65,0.76$ である. $\Delta T=10$ 年と 20 年の 場合は, 凸型分布 (Fig. 3)をしていて, 区間内に最頻值 （モード）が含まれており，これらの值で差し支えない。 しかし, $\Delta T=30$ 年の場合は, 非対称性が著しい J 字型 分布をしており, “平均土標準偏差”では最頻值 $\left(P_{q}=1\right)$ が推定区間外になり，区間推定の方法として問題であ る.そこで, 確率密度の高い部分を優先し, 信頼水準を 68.3\%（正規分布で平均土標準偏差に相当する）之すれ ば, $0.75<P_{q} \leq 1$ となり, Fig. 3 の確率分布から受ける 印象に整合する. 区間推定の範囲は, $\Delta T=10$ 年と 20 年では余り重ならないが, 20 年と 30 年はかなり重なっ ている.

データセット IV について同様な計算をすると, 地震 発生確率 $P_{q}$ の分布は Fig. 6 のようになる. 各予測期間 に対応する平均, 分散, 標準偏差は

$$
\begin{array}{r}
\Delta T=10 \text { 年: } \bar{P}=0.25, v=0.0080, s_{q}=0.089 \\
20 \text { 年: } \bar{P}=0.57, v=0.0162, s_{q}=0.127 \\
30 \text { 年: } \bar{P}=0.79, v=0.0150, s_{q}=0.122
\end{array}
$$

である. データセット I に比べ， $P_{q}$ の分散が半分程度以 下に減り, $\Delta T=30$ 年の場合屯凸型分布となる. 形式的 には, 地震数が増えて誤差の標準偏差が小さくなるの で, 確率推定の精度が向上している. しかし， $\Delta T=30$ 年の区間推定は, データセットIが $0.75 \leq P_{q} \leq 1$ で, データセット IV が $0.79 \pm 0.122$ であるので, その区間

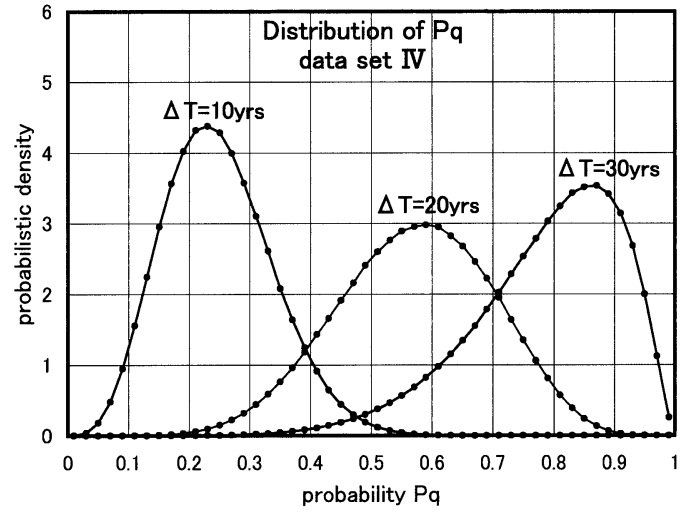

Fig. 6. Distribution of the probabilities, $P_{q}$, of earthquake occurrence for the data set IV.

の長さはほとんど同じである.

\section{§4. 考察}

尤度の定義に, 最後の地震からの経過時間を考慮し, 厳密な地震発生確率の計算方法を議論してきた。しか し, 得られた確率值を解积する際には, 使用したデー夕 セットや仮定した事前分布に注意する必要がある.

宮城県沖で発生した歴史地震については, 地震調査研 究推進本部地震調查委員会 $(2000)$ に記されているよう に，瀬野 (1979), Utsu (1984) などの報告がある．それら には宮城県沖で発生した可能性がある古い地震がいくつ あ掲載されているが, 門外漢の筆者には, 宮城県沖地震 として採用することの当否は分加ない.ここでは 4 つ のデータセットについて, 地震発生確率の計算を行い比 較した。

地震発生確率の計算の際に, 標本平均 $\bar{x}$ 之標本分散 $s^{2}$ を母集団パラメータ $\mu, \sigma^{2}$ の代わりに用いて，(17) 式で 計算することがあるが, Davis et al. (1989) が指摘して いるように, このやり方は, 最後の地震から予測時点ま での経過時間，および標本值 $\bar{x}, s^{2}$ と母集団パラメー夕 の性質の相違を無視している. デー夕数が少ないと推定 值の誤差が大きくなり, 計算結果が確率の期待値から相 当偏っている恐れがある. 特に, 得られた確率值が 0 ま たは 1 に近く, Hessian 行列 [井元 (1999)] を用いて求 めた誤差範囲の一部が負になる場合や 1 を超えるよう な場合は, 偏りが著しい. 加えて, $\mu, \sigma^{2}$ として最尤推定 值 $\left(\bar{x}, s^{2}\right)$ を使っていても, 確率計算の (17) 式は $\mu, \sigma^{2}$ に ついて非線形であり, 得られた確率值はもはや確率の最 尤推定 $\left[P_{q}\left(T_{p}, T_{p}+\Delta T\right)\right.$ の分布の最頻値 $]$ とならない.

Davis et al. (1989) が使用した条件は今回のあの之異 なり, 事前分布 $\pi(\mu, \sigma)=1$ に相当する. この場合は, ベイ ズの定理から期待される $\mu, \sigma$ の同時密度分布が 
$h\left(\mu, \sigma \mid n, \bar{x}, s^{2}, x_{p}\right) d \mu d \sigma^{2}=\frac{L\left(\mu, \sigma^{2}\right)}{C} d \mu d \sigma$

で与えられる.ここで $C$ は

$$
C=\int_{\sigma=0}^{\infty} \int_{\mu=-\infty}^{\infty} L\left(\mu, \sigma^{2}\right) d \mu d \sigma
$$

である，詳しい説明は省略するが，(11) 式以下あ少しず つ式が変わる. $\Delta T=10$ 年の地震発生確率（点推定）は 0.28 で, 今回求めた確率 (点推定) と同じである. しか し, 20 年と 30 年では 0.69 と 0.87 であり, 今回求めた 值より大きい。

今回は $\pi\left(\mu, \sigma^{2}\right)=1$ を採用したが，様々な事前分布が考 えられる. 正規分布の平均 $\mu$ は, 変動範囲に何ら制約が ないので，全区間で一様であると仮定するのは自然な発 想であろう. 分散 $\sigma^{2}$ は, 变動範囲 $\left(0 \leq \sigma^{2}<\infty\right)$ の両端の 条件が異なるので, 全区間について一様なあのが適当で あるとは限らない，標準偏差 $\sigma$ につて一様なモデル $\pi$ $(\mu, \sigma)=1$ は, $\pi\left(\mu, \sigma^{2}\right)=1 / \sqrt{\sigma^{2}}$ の場合に該当し, $\sigma^{2}$ の小さ い方に大きな加重がかかることになる.

固有地震または繰り返し発生している地震系列では, 異常に長い地震発生間隔 (例えば平均の 100 倍を超える ようなもの）や異常に短いもの（平均の 100 分の 1 以 下）は想定しにくい. 分散 $\sigma^{2}$ は事実上の上限があると考 えられるので, $\sigma^{2}$ が小さい方に加重がかかったモデルが 好都合であろう。しかし, 地震系列を選び出す際は, 発 生間隔が揃ったもの, すなわち, $\sigma^{2}$ の小さいものが選ば れやすいことを考慮するならば, $\sigma^{2}$ の大きい方に加重が かかったモデルむ否定できない.

事前分布 $\pi\left(\mu, \sigma^{2}\right)=1$ は, 見方を变えればデータや地震 学的な知識に基づくあのでないので, 得られた結果の信 頼性すおのずから限界がある. Fig. 7 はいくつかの報告 等 $[$ 地震調査研究推進本部地震調査委員会長期評価部会

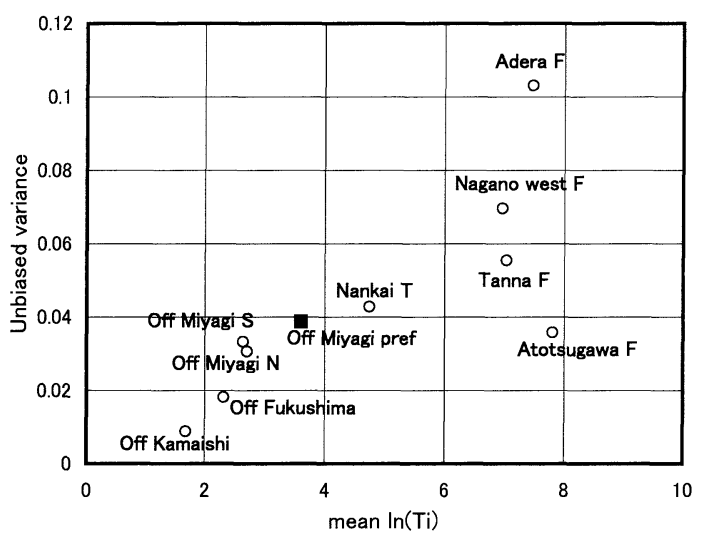

Fig. 7. Distribution of the mean and unbiased variance of data, $x_{i}$, observed at some characteristic earthquake sequences.
(1999), 長谷川 (2002), 長谷川・他 (2002)] 加ら求めた $x_{i}=\ln \left(T_{i}\right)$ の標本平均 $\bar{x}$ 之標本不偏分散 $n s^{2} /(n-1)$ との 関係を示したものであるが，平均 $\bar{x}$ が大きくなるにつれ て, 分散が大きくなる傾向がある. しかし，平均值が小 さい事例は, 同程度規模の地震がほぼ等間隔で発生して いる事例として選び出された結果であり, 無作為抽出で はない，そのため，今回使用した事前分布を必ずしも否 定するあのではない，釜石沖の場合は，一つのアスペリ ティで発生していると見なされており [Matsuzawa $e t$ al. (2002)], 固有地震の時間間隔分布や発生時期の予測 を調べるうえで参考になる. 今後の推移が注目される.

地震調査委員会では各地の活断層や地域の地震活動を 精力的に進めており, 蓄積された資料を用いて事前分布 を求めることが望まれる. 特定の断層や震源地について 見ると, 地震数が少ないので, 分散に関してだけであ事 前分布が得られれば, 長期発生確率の精度が向上するこ とが見込まれる.

今回は, 地震発生確率を求めるための厳密な計算方法 を提起することを大きな目的としており, 基本的に地震 調査委員会 (2000) と同じ条件 (データセットIで, 予測 期間 10 年, 20 年, 30 年) で発生確率を計算し, 結果を 比較した。地震調查委員会 $(2000)$ が発表した発生確率 值を点推定値 (確率の期待值) と比較すると, 予測期間 20 年抢よび 30 年の場合に計算方法による差が認めら れる.しかし、いずれの予測期間についてあ, 今回行っ た区間推定の範囲内である.地震発生確率の分布 (Fig. 3) から分かるように, 調查委員会の值はさほど大き過ぎ るものでなく, 点推定值との差は統計的に有意ではなさ そうである. また，区間推定で，予測期間 20 年と 30 年 の範囲がかなり重なり合っており，両者を区別する十分 な根拠がないことを示唆している。このように統計的に 有意な差がない場合に，予測結果の相違をどのように扱 うのが適当であるか今後検討する必要があろう.

\section{§ 5. 結論}

繰り返し発生した $n+1$ 個の大地震または固有地震の 発生時が知られているが，パラメー夕值について事前の 情報がない場合について, 対数正規分布モデルによる地 震長期発生確率の計算方法をべイズの定理を用いて求め た. 事前分布として $\pi\left(\mu, \sigma^{2}\right)=1$ を採用するならば，最後 の地震から次の地震までの間隔 $T$ は, $\sqrt{n-3}(\ln (T)-$ $\bar{x}) / \sqrt{(n+1) s^{2}}$ が自由度 $n-3$ の $t$-分布に従うので, その 分布は容易に計算できる. $\bar{x}, s^{2}$ は時間間隔の対数の標本 平均と標本分散である。一方, ベイズの定理を使えば, 母集団のパラメータ $\mu, \sigma^{2}$ の確率分布が求まるので，与 えられた予測期間内に次の地震が発生する確率 $P_{q}$ の確 
率分布も計算できることを示した。

地震調查研究推進本部地震調查委員会 (2000) が宮城 県沖地震として同定したデータセットで長期発生確率 $P_{q}$ の分布を計算すると, 2001 年 1 月 1 日から 10 年間 に発生する確率の期待值（点推定）は地震調査委員会の 値（約 0.3）に近い. 20 年間, 30 年間の発生確率は調査 委員会の值より小さい. 他のデータセット（3 例）につ いても計算したが, 同様な結果であった.

発生確率 $P_{q}$ の区間推定を “平均土標準偏差” で表す 之, 10 年, 20 年, 30 年の場合それぞれの值は $P_{q}=0.28$ $\pm 0.126,0.62 \pm 0.195,0.80 \pm 0.194$ となり，各区間内の 確率は $0.67,0.65,0.76$ である. $\Delta T=30$ 年の場合は, 非 対称性が著しい J 字型分布をしており, 確率密度の高い 部分を採用すれば, $0.75<P_{q} \leq 1$ となる.

なお，今回使用したパラメータ $\mu, \sigma^{2}$ の事前分布は $\pi\left(\mu, \sigma^{2}\right)=1$ であるが, 今後その妥当性を検討評価する必 要がある.

\section{謝辞}

本研究の一部として, 統計数理研究所の共同研究「地 震発生の続発生・間欠性の調査研究」（課題番号 14- 共 研 2031, 尾形良彦教授担当）の費用を使用しました．東 京大学地震研究所山科健一郎氏および匿名の査読者から は多々ご指摘をいただきました。これらの方々および関 係者に䔣礼申しあげます。

\section{文献}

Bakun, W. H. and A. G. Lindh, 1985, The Parkfield, California, earthquake prediction experiment, Science, 229, 619-624.

Davis, P. M., D. D. Jackson and Y. Y. Kagan, 1989, The longer it has been since the last earthquake, the longer the expected time till the next?, Bull. Seism. Soc. Am., 79, 1439-1456.

長谷川 昭, 2002, 的中した地震発生予测, 科学, 72 , $581-583$.

長谷川安秀・橋本徹夫 ・ 草野富二雄 - 吉川一光 - 大西星 司, 2002, 東北地方における固有地震的地震活動の検 出, 日本地震学会講演予稿集, 2002 年度秋季大会, C 36.

今村明恒, 1933, 南海道沖大地震の謎, 地震 $1, \mathbf{5}, 607-$ 626.

井元政二郎, 1999, 更新過程における予測確率の誤差, 地震 $2,52,337-340$.

石橋克彦・佐竹健治, 1998, 古地震研究によるプレート 境界巨大地震の長期予測の問題点一日本付近のプレー
卜沈み込み帯を中心として一, 地震 2, 50, 別冊, 1-21. 地震調査研究推進本部地震調査委員会, 2000, 宮城県沖 地震の長期評価, インターネット公開.

地震調查研究推進本部地震調查委員会, 2001, 長期的な 地震発生確率の評価手法について, 99pp.

地震調査研究推進本部地震調査委員会長期評価部会, 1998, (試案) 長期的な地震発生確率の評価手法及び その適用例について, 73pp.

地震調查研究推進本部地震調査委員会長期評価部会, 1999, (改訂試案) 長期的な地震発生確率の評価手法 について, 試案「長期的な地震発生確率の評価手法及 びその適用例について」に対する意見募集の結果及び 寄せられた意見に対する長期評価部会の考え方につい て, 55-138.

Matsuzawa, T., T. Igarashi and A. Hasegawa, 2002, Characteristic small-earthquake sequence off Sanriku, northeastern Honshu, Japan, Geophys. Res. Lett. 29, 11, 1543, doi: 10.1029/2001GL014632, 2002.

森口繁一・宇田川銈久・一松 信, 1956, 岩波数学公式 I一微分積分・平面曲線一, 岩波書店, 318pp.

Nishenko, S. P. and R. Buland, 1987, A generic recurrence interval distribution for earthquake forecasting, Bull. Seism. Soc. Am., 77, 1382-1399.

Ohtake, M. and H. Ueda, 2002, Statistical forecast of the next Miyagi-oki, northeast Honshu earthquake, Tohoku Geophys. J., 36, 299-310.

Ogata, Y., 1978, The asymptotic behavior of maximum likelihood estimators for stationary point processes. Ann. Inst. Statist. Math., 30, 243-261.

力武常次, 1976 , 地震予知論入門, 共立全書, $212 \mathrm{pp}$.

Savage, J. C., 1993, The Parkfield prediction fallacy, Bull. Seism. Soc. Am., 83, 1-6.

瀬野徹三, 1979, 宮城県沖に予想される地震について, 地震予知連絡会会報, 21, 38-43.

島崎邦彦・河瀬和重・佐竹健治 - 鈴木康弘 - 尾形良彦 井元政二郎・隈元 崇, 地震の繰り返し発生に関する 統計モデルの検討, 日本地震学会講演予稿集, 1998 年度秋季大会, P136.

宇津徳治, 1972, 北海道周辺における大地震の活動之根 室南方沖地震について, 地震予知連絡会会報, 7, 7-13.

Utsu, T., 1984, Estimation of parameters for recurrence models of earthquakes, Bull. Earthq. Res. Inst., 59, 53-66.

宇津徳治, 1998, 地震活動パターンと大地震の長期予測 一繰返し・空白域・静穏化・先行地震・移動・相関な ど一, 地震 2, 50, 別冊, 73-82.

Working Group on California Earthquake Probabilities, 1995, Seismic hazards in southern California: probable earthquakes, 1994 to 2024, Bull. Seism. Soc. Am., 85, 379-439. 